\title{
Shifting frontiers of transcendence in theology, philosophy and science
}

\author{
Author: \\ Cornelius W. du Toit ${ }^{1}$ \\ Affiliation: \\ ${ }^{1}$ Research Institute for \\ Theology and Religion, \\ University of South Africa, \\ South Africa

\section{Correspondence to:} \\ Cornel du Toit \\ email: \\ dtoicw@unisa.ac.za \\ Postal address: \\ PO Box 392, UNISA 0003 \\ South Africa \\ Dates: \\ Received: 01 June 2010 \\ Accepted: 20 June 2010 \\ Published: 07 June 2011 \\ How to cite this article: \\ Du Toit, C.W., 2011 \\ 'Shifting frontiers of \\ transcendence in theology, \\ philosophy and science', \\ HTS Teologiese Studies/ \\ Theological Studies 67(1), \\ Art. \#879, 10 pages. DOI: \\ 10.4102/hts.v67i1.879
}

(C) 2011. The Authors Licensee: OpenJournals Publishing. This work is licensed under the Creative Commons Attribution License.
This article dealt cursorily with developments in theology, philosophy and the sciences that have contributed to what one might call horizontal transcendence. The premise is that humans have evolved into beings that are wired for transcendence. Transcendence is described in terms of the metaphor of frontiers and frontier posts. Although the frontiers of transcendence shift according to the insights, understanding and needs of every epoch and world view, it remains transcendent, even in its immanent mode. Diverse perceptions of that frontier normally coexist in every era and we can only discern a posteriori which was the dominant one. Frontiers are fixed with reference to the epistemologies, notions of the subject and power structures of a given era. From a theological point of view, encounter with the transcendent affords insight, not into the essence of transcendence, but into human self-understanding and understanding of our world. Transcendence enters into the picture when an ordinary human experience acquires a depth and an immediacy that are attributed to an act of God. In philosophy, transcendence evolved from a noumenal metaphysics focused on the object (Plato), via emphasis on the epistemological structure and limits of the knowing subject (Kant) and an endeavour to establish a dynamic subject-object dialectics (Hegel), to the assimilation of transcendence into human existence (Heidegger). In the sciences certain developments opened up possibilities for God to act in non-interventionist ways. The limitations of such an approach are considered, as well as promising new departures - and their limitations - in the neurosciences. From all of this I conclude that an immanent-transcendent approach is plausible for our day and age.

\section{Introduction}

\section{Post-transcendence?}

If we are living in a post-transcendent age, why this renewed interest in the subject? Why does metaphysics keep rearing its head in a post-metaphysical era ${ }^{1}$ The answer offered in this article is that humans, being self-transcending and wired for transcendence, are ineluctably bound to keep shifting the frontiers of transcendence, but at the same time cannot exist without them. ${ }^{2}$ At most transcendence is reinterpreted to conform to our most recent experience and interpretation of it. In other words, what characterises people as transcending beings is not just their belief in the existence of an absolutely transcendent God; transcendence is integral to their being. Radical reinterpretation of transcendence started with the 15th century scientific revolution and reached a zenith in our time, to the point where we are giving up metaphysics altogether. So whilst it seems that transcendence can be 'domesticated' and secularised, it cannot be eliminated without radically changing human nature. The altered view of transcendence is a by-product of secularisation and the growing impact of a techno-scientific world view. Probably a new cosmology (new perception of space and time), new biological, cognitive and brain sciences, as well as new philosophical ideas, have done most to change our concept of transcendence. In view of these influences theology tries to retain its credibility by reinterpreting religion for a technoscientific age.

A revised version of transcendence not only affects the existence and nature of an absolutely transcendent God, but also has implications for humans as self-transcending and transcendenceoriented beings, such as fresh insight into our thought processes, philosophies and epistemologies. If crossing frontiers is a hallmark of human nature, it means we are wired for transcendence. We not only 'erect' frontiers but also cross them and shift them to accord with the insights and challenges of our age. Crossing a frontier is not to demolish it but to shift it - after all, new

1.Berger (1993:2) believes that metaphysics (not in the sense of Platonic noumenal metaphysics), like the philosophy of Heidegger and Levinas, rescues transcendence from the clutches of the modern subjectivism that destroyed it. In fact, transcendence is the secret power of metaphysics.

2.This applies to religion as well: 'Religion was not something tacked on to the human condition, an optional extra imposed on people by unscrupulous priests. The desire to cultivate a sense of transcendence may be the defining human characteristic' (Armstrong 2009:19). 
frontiers keep materialising. To some people God must invariably come to humankind perpendicularly from 'above' or from some 'beyond'. But we are only able to conceive of transcendence via our biological equipment. And even when God is perceived as immanently active in this world, he remains transcendent and the questions are no different from those asked by people who see him as descending from 'above' or 'beyond'. The question raised by secular transcendence is not what has replaced transcendence - that would mean asking what has replaced human beings - but how the frontiers of the transcendent have shifted in our global, techno-scientific dispensation.

One could say, without generalising, that the following aspects of traditional Christian belief are no longer taken literally by many people: belief in miracles that are counter to natural laws; belief in eternal life after death ${ }^{3}$ or eternal torment in hell; sin as integral to human nature; and ascribing disasters, personal suffering and evil to God's will. ${ }^{4}$

Transcendence is characterised by the unknown, especially its menacing aspect (cf. Rudolf Otto). Mostly the unknown manifests itself in the form of incomprehensible, radically transcendent evil. If one can explain the unknown, it becomes transparent and less ominous. Even if we do not understand an unknown disease, it becomes less threatening once it has been medically described, explained and labelled. But radical evil has no name; one cannot calmly speculate about it and it cannot be comfortably accommodated in sociological or psychological theories. It may be easier to understand the ineffability of transcendence when it encounters humans in a negative way than when it assumes a positive form. ${ }^{5}$

Belief in God or the supernatural remains human belief. The humanly immanent aspect of faith is studied via the nature and operation of human consciousness, thought (philosophy), language (metaphor), physicality (biology, brain sciences) and culture (sociology, psychology, etc.). We cannot divorce religion or religious experience from these

3.For an overview of the relation between death and transcendence in various religions and cultures, see Chidester (1990). To Christians the stories of Jesus' death and resurrection have become paradigms of their own lot (Chidester 1990:194-196). Chidester (1990:215-216) refers to the role of scriptures (in Judaism, Christianity and Islam) in this regard: 'In each tradition, the book symbolized a transcendence of death ... The technology of the book, therefore, entered into both the cultural and mythic transcendence of death.' For a different slant on the role of death in presentday societies, see Du Toit (2009).

4.Current popular culture teems with examples of superterrestrial and supernatural beings who play a role in human lives: demons, angels, ghosts, animated nature and magic forces that control human life. In popular culture immanent transcendence puts the accent on its menacing aspect (culture of violence in filmic media, natural disasters, Armageddon, aliens from outer space that threaten life one earth, etc.). disasters, Armageddon, aliens from outer space that threaten
For a postmodern view of the end-time, see David Wood (2007)

5.When confronted with inconceivable evil like the suffering of Jews in concentration camps and victims of natural disasters speculative theories are inappropriate. These events leave us speechless. It is the nihil negativum. For instance, one cannot speculate about goodness without inquiring into truth (empirical facts). With reference to tragedy Janz (2004:177) writes: 'And the point is that in tragedy, the question of the good (i.e. the utter absence of it) cannot be abstracted from the real, that is the empirically real.' Theorising about evil or trying to fathom its essence often leads us to discover its banality, as described by Hanna Arendt in the context of Eichman's evidence on his responsibility for the death of thousands the context of Eichman's evidence on his responsibility for the death of thousands of Jews in concentration camps. Here was a 'perfectly ordinary' family man, which in fact underscores the banality of evil (Prime Evil). In a way the negative form of transcendence complements positive (divine) transcendence. Describing theolicitirmed by everybody who has had a transcendent experience that is not theologically, philosophically or scientifically explicable. dimensions, because without them religion and religious experience make no sense.

Transcendence relates to the human experience of dependence - especially at a religious level. At an anthropological level it relates to our experience of incompleteness, lack of fulfilment and openness. Epistemologically it relates to our view of the world and of humans as thinking subjects. And at a religious level we no longer depend on gods and powers 'beyond' us but on powers and influences around us.

\section{Transcendence as a frontier, an 'in-between' zone and a zone of encounter}

Transcendence is the antonym of immanence. But that is misleading. Immanence is not unambiguous, readily understandable - it is paradoxical, ambivalent, both pluralistic and dualistic and enigmatic. Immanence is fraught with transcendence - so much so that one could argue that the very experience of this-worldly transcendence compelled us to posit metaphysical transcendence in the first place (metaphysical idealism).

In the context of this article transcendence has to do with the experience and erection of frontiers, be they the frontiers of empirical reality, mental frontiers or inbuilt frontiers in the brain. Humans are confined by their biological nature: their consciousness of space and time sets limits. ${ }^{6}$ Then there are limits imposed by ignorance, sensory and physical limits, the threat of the unknown (radical evil), mortality and a world in constant flux. Like language (e.g. its metaphoric structure cf. Du Toit 1984), the human mind is transcendentally structured.

Most frontiers that we encounter can be crossed, albeit not always easily. Theoretically, some frontiers can never be crossed and we have to be content with highly speculative 'conjectures' about what lies beyond them. The Kantian Ding an sich is such a frontier. So is God's being. The reason why natural laws are what they are is another. Examples of physical frontiers are barriers set by nature, like a mountain range, forest or the sea; distance (including as yet insurmountable outer space) is a frontier that includes time. Time, too, is a physical limit: we have to wait for tomorrow and the remote past often remains shrouded in mystery. There are the limitations of our measuring instruments that prevent us from exploring beyond their capacity. The limits imposed by human consciousness are physical but also theoretical and abstract and to our experience often more complex than physical frontiers. They range from boundaries within our consciousness, like the boundary between mind and body, to the consciousness or selfconsciousness dichotomy and to the division within selfconsciousness when I engage in inner conflict or dialogue. There is also the division between one's inner world and the

6.For Otto Weber's connection of space and time with transcendence, see Weber (1972:732ff). 
world outside: the division between the I and the (always unpredictable) other (person or object) outside me; the limit of my future or death; God as a limit (the Totally Other); the openness of life experienced as a limit. There are limits set by laws and authoritative institutions like the church, which have epistemological and moral implications. Underlying all limitations is their connection with time and space and with knowledge, perceptions, consciousness and experience. ${ }^{7}$ Frontiers or limits as described here confront us with the problem of dualism. The notion that post-Cartesianism spells the end of dualism is a myth.

The transcendent can be perceived as personal or impersonal objects or forces. Personalising transcendent agents confers an ethical dimension in that they are seen as good, evil or neutral (chance). The (un)knowability of these forces determines our epistemologies, their self-revelation, theology and religions.

To take our metaphor of frontiers or limits further, they are crossed when openings (think of border posts) arise. In science such openings are created by new instruments (Galileo's telescope), new theories or interpretive frameworks. As a rule rivers or mountain ranges can only be crossed at certain points. Normally border posts are erected at these places, resulting in cross-border traffic, but they also inevitably entail filters (like customs houses). Some traffic is not allowed to cross or certain conditions have to be met before it is allowed to cross. The following 'border posts' may be noted in the Christian religion. The cardinal one is the birth of Christ, the opening through which God entered the world to dwell amongst humans. In his turn Christ himself is an opening - the 'way' or the 'door' (John's Gospel) - giving access to God. Later miracles increasingly became openings for communication with God, along with prayer and the working of the Spirit. But cross-border traffic is two-way.

Religiously a frontier is an in-between zone ${ }^{8}$ where opposing forces meet. It can also be called a zone of revelation, a place of encounter, a causal joint, the between ('zwischen') or the hinge. The revelation is usually described subjectively: God appears in a vision or dream (Jacob's ladder linking 'heaven' and 'earth'), a Damascus experience (Paul). The person assigns an 'ordinary' experience extraordinary meaning

7.Karl Heim (Holmstrand 1980:91-94) distinguishes between consciousness transcendence (T2), when the transcendent is not accessible via the sense transcenden senses; experiential transcendence (T3), which is not accessible to human experience (e.g. a square circle); semantic transcendence (TS), which is objectively or in principle God's aseity is an example (aseity is existence originating from and having no source other than itself).

8. For lack of space I cannot elaborate on the in-between, although it is a hallmark of human existence. It is beautifully depicted in Plato's Symposium where Socrate recounts his experience with Diotima to clarify what love (eros) is (she was an ancient female philosopher and tutor of Socrates. In Greek her name also connotes a complete woman as well as the Greek goddess of love. Her ideas are the origin of the concept of platonic love). Eros cannot be divine, because he consists of opposing entities. His father, Poros, the god of plenty, was seduced by Peni (poverty). Because of this background he is perennially poor but occasionally rich, (poverty). Because of this background he is perennially poor but occasionally rich, oscillating between abundance and penury, wisdom and folly. Here Eros is a symbo of desire that always vacillates between fulfilment and unfulfilment. It is epitomised by someone who not only oscillates between penury and abundance, but who is as evidenced by the history of eroticism in human life (see Du Toit [2010:65-67]; as evidenced by the history of eroticism in hum
also see the seminal work by Desmond [1995]). and expresses the pivotal experience in appropriate images: ecstasy; holy ground; rebirth; enlightenment (Buddhism, mysticism); Being that manifests itself in moments of illumination (Heidegger's Lichtung); a word event (Ebeling's Wortereignis) when ordinary language becomes a lifechanging event.

From the human side of the pivotal point the transcendent or supernatural first has to be revealed, then encountered, understood and interpreted, otherwise no revelation takes place. From the divine side there is self-revelation (incarnation) of the Godhead, as in a burning bush, historical event, Jesus, the Word (Logos) or the Spirit.

But even in incarnate form the deity still has to be 'different' and radically different at that, otherwise it remains a purely human affair. ${ }^{9}$ The earthly Jesus was different in the sense that he imbued mundane reality with transcendence, accomplishing something radically new by means of ordinary human acts. Examples are his flouting of human laws by consorting with social outcasts and showing forgiveness, empathy and love that flew in the face of the conventions of his day. These are perfectly ordinary responses, whose rarity displays transcendent features. It implies that ordinary human thought and behaviour can accommodate the transcendent. The divine manifests itself in and through love, hope, faith, compassion, forgiveness, vision, interaction with others. Consequently, transcendence does not fall flat when it manifests itself in normal human guise but offers a 'different' dimension. In fact, transcendence wholly divorced from humanness is inconceivable.

Yet to modern people God's 'traditional way' of revealing himself and encountering humans is problematic: miracles that defy natural laws as we have come to know them; metaphysical language and mental constructs that no longer make sense. Nowadays many people want these frontiers of encounter to be shifted. We now turn to theological attempts to do justice to the transcendent side of immanent theophanies and experiences of the divine.

\section{Transcendence in theology}

The Old Testament world view saw humans as restricted beings, as is evident in the creation stories. ${ }^{10}$ Miracles formed part of the world view of antiquity and should not

9. Anthropomorphic references to God are well known. In the Old Testament he is 'guilty of blatant favouritism, and his somewhat arbitrary choices ... set human beings murderously against each other' (Armstrong 2009:43).

10.God created from nothing and did so by demarcating boundaries between the following dimensions: light and darkness; dry land and ocean; water in the sky and water on earth; humans and animals; man and woman; and weekdays and sabbath. The second creation story erects a frontier between the human spirit and matter. Following the expulsion from paradise, a frontier is fixed between life and death. These physical frontiers run through the whole of life, including religious life: temporal boundaries (the sabbath, feasts as holy days) and spatial boundaries (holy places). There is a frontier or zone where God is encountered boundaries (holy places). There is a frontier or zone where God is encountered (the temple), but with the exile this frontier necessarily shifted to the word: 'I J's creation story had been a myth of Solomon's temple, P's was the myth of the virtual temple he was encouraging the exiles to build by means of the new rituals of separation' (Armstrong 2009:51, 82). The temple was replaced by the Torah as New Testament Jesus became the Shekinah, the place where God is encountered (Armstrong 2009:86). 
be regarded as breaches of natural law in our modern sense. Hence they did not have the 'offensive' character they have today and were simply signs of the presence of God's love and his faithfulness to his people. The Old Testament contains numerous examples of how God manifests himself in normal human events, giving them new meaning. He is a god of promises who gives his word (covenant) to humankind. He is the god of history who journeys with them through life. Although in essence he remains transcendent and no image may be made of him, he enters into human life.

God is the one source of all transcendence. In his transcendence (total otherness) he is unknowable. Humans cannot ascend to him: it is he who communicates himself to them through revelation. When God reveals himself it is often an overwhelming event that completely stuns human beings. He comes to them directly from on high ('senkrecht von oben' - Barth). There is an absolute divide between humanity (mendax) and God (verax), which inevitably leads to paradoxes. God's revelation does not divulge the mystery of his being. It is at most an emanation of the Absolute (Plotinus), which by analogy tells us something about his grandeur or otherness, for revelation does not reveal his essence (deus nudus). Revelation is the revelation of hiddenness (Berkhof). The transcendent remains a deus absconditus.

In theology the question of God's transcendence has two focuses. Viewed from our side, humans must strive to know and encounter the unknowable (which includes the dialectical inversion: it is he who knows and encounters us). Viewed from the other side it is a matter of how God acts in the world. ${ }^{11}$ From the human perspective God can only be known and understood by way of filters. In the history of religions the principal filters have crystallised in language in the form of metaphors, analogies and symbols; ${ }^{12}$ exegetical filters in the form of proofs of God's existence and apophatic theologies; experiential filters in the form of rituals, rites and sacraments; the filter of mysticism; Christian dogmatic filters according to which God can only be approached via the faith, Jesus and Mary. The filters are unavoidably marked by some form of dualism, because the human and the divine are on opposite sides. The human side hinges on the divine side in a process where we look at one reality (the earthly one) whilst seeing and experiencing something else (the transcendent). That is Heidegger's distinction between earth and the world that it opens up (Welt und Erde). From the earth (matter) of an artwork a meaningful world is born. That is achieved by the metaphor, whose graphic side opens up an interpretive dimension without reducing the artwork to that meaning. Hence the way God is seen, known and encountered is simply one of seeing ourselves and our existence in a new light. ${ }^{13}$

11.To some extent this distinction corresponds with Augustine's view of the transcendent as 'the way toward God, and the way of God' (Brons 2002:181).

12.Cases in point are paradoxical (diaphoric) theological concepts that are linked together. Therefore Berkhof characterises God by means of the binary concepts of holy love (1973:124-140); defenceless power (141-147); and inconstant faithfulness (148-155).

13.Consequently Armstrong (2009:271), commenting on Rahner, writes: 'Thus every act of cognition and every act of love is a transcendent experience because it compels us to reach beyond the prism of selfhood.'
All true knowledge about human beings starts with 'knowledge' of God. But all knowledge about God is nothing but 'new' knowledge about human beings. God does not reveal mystery, he sheds light on it. Apophatic and negative theologies can do no more than offer insight into human selfunderstanding - which inevitably derives from the world view, thinking and questions of the age in which people live. That is why frontiers of encounter and understanding have to be shifted. When religious conceptions become fossilised because the world view in which they once made sense is now archaic, the medium of encounter between transcendence and immanence must change. ${ }^{14}$ That is what is happening in our time. ${ }^{15}$ We interpret our transcendent 'wiring' differently from the way the biblical authors did. That is partly attributable to science and the rediscovery of our 'divine' nature, which not only microcosmically mirrors the macrocosm, but in its mortal fragility also carries our consciousness of infinity. ${ }^{16}$ This is no metaphysical, noumenal transcendence ${ }^{17}$ but an immanent, this-worldly transcendence experienced as an event. ${ }^{18}$ Only by returning to the earthiness of faith can we free God from his worldlessness (Weltlosigkeit Gottes) and transcendent reality from Platonic incarceration in a realm of ideas (heavenly kingdom or noumenal metaphysics).

Religion based on metaphysical, noumenal attributes of God is vacuous. What do we mean by God's omnipresence, omniscience, eternity, omnipotence? These categories are beyond our comprehension and are best avoided. ${ }^{19}$ Philosophy

14.An example is the so-called Vermittlungstheologie of Barth, Tillich and Bonhoeffer (see Berkhof (1973:116)).

15.My conception of shifting the frontier should not be confused with a Bultmannian demythologising process. Stripping the temporal veil does not mean revealing the eternal substance behind it (noumenal metaphysics). The temporal veil is like the layers of an onion. We never find the naked truth behind it, because truth lies in each step towards it: all are parts constituting the whole. The meaning of time lies in that veil. Searching for a universal, eternally true eidos was the Sisyphus labour of traditional metaphysics. Seeing the medium through which we experience transcendence as a shifting frontier is simply a matter of historically determined epiphanies of the transcendent. It does not describe the transcendent but describes our reality, just as humans do not expound the transcendent but are expounded by it Here one is reminded of Bonhoeffer, who maintained that are expounded by it. Here one is reminded of Bonhoeffer, who maintained that Bultmann's demythologisation does not go far enough - 'that is, that virtually all religious terminology, and not only that belonging to the three-tiered universe, needs to be demythologized: "revelation", "redemption", "sin", "incarnation", "resurrection" and, as Bonhoeffer himself insisted, even "God" (Janz 2004:181) By the same token he regards the question of what Jesus is to people today 'as a genuine question of non-resolution', for it concerns empirical reality and the possibility of reconciliation (Janz 2004:182). That is a radical shifting of frontiers, in Bonhoeffer's case necessitated by the demands of his time.

16.We never question the reality of what goes on in our minds. Ryle (1949:16) already pointed it out: "He [a human person] can take a (non-optical) "look" at what is passing in his mind...; he can also reflectively or introspectively watch, without any bodily organ of sense, the current episodes of his inner life. This self-observation is also commonly supposed to be immune from illusion, confusion or doubt. A mind's reports of its own affairs have certainty superior to the best possessed by its reports of matters in the physical world. Sense perception can, but consciousness and of matters in the physical world. Sense perception can, but consciousness and introspection cannot, be mistaken or confused.' Using the same idiom, one might say that a person who is conscious of God or the transcendent does not doubt its reality

7.For lack of an apposite term I resort to the Kantian notion of noumenon, to express the belief that we can metaphysically know (think) the Absolute or Transcendental (see the German word Wesensschau). Perhaps it all started with the focus of the ancient Greek philosophers on being - which they did to avoid subjectivity.

18. Hick (1997:51) adopts the same approach: 'We cannot know it [the transcendent] as it is in itself, but only as it affects us. In Kantian terms, we do not experience the divine noumenon, but a range of divine phenomena to the formation of which our human religious concepts have contributed.' Also see Hick (2006:137-145).

19.Armstrong (2009:125) puts it emphatically: 'God is plainly not a rock, a gentle breeze, a warrior or a creator. But when we come to the more conceptual descriptions of God, we find that we have to deny these too. God is not Mind in any sense that we can understand; God is not Greatness, Power, Light, Life, Truth Imagination, Conviction, Understanding, Goodness - or even Divinity. We cannot even say that God "exists" because our experience of existence is based solely on even say that God "exists" because our experience of existence is based solely
individual, finite being whose mode of being bears no relation to being itself.... 
rejected the attempt at a metaphysical Wesenschau, as will be seen below. There are many examples of new perceptions of these 'filters' in theology. The accent is on the human (incarnated) God; the kenotic Jesus; the suffering God who journeys with us through history (including the history of natural evolution). As God's revelation Jesus is the 'face', not of God, but of a human being - that is, of what human beings can become. The accumulation of metaphysical luggage is to be found in the Christ of religion, not the historical Jesus. ${ }^{20}$ Jesus unleashed a unique kind of transcendence on our historicity by opening up a future for ordinary folk in a human way. In that way human compassion, concern, forgiveness and prayer acquire a transcendent character. But that transcendent dimension is never guaranteed, or it would no longer be transcendence..$^{21}$

The second focus is how to see God's actions in the world. That is particularly problematic in our time, because people are no longer at home with miracles and divine acts that arbitrarily contravene the laws of nature. All that started changing by the 15th century with the scientific revolution. I shall deal with it in the section on transcendence in the sciences.

\section{Transcendence in philosophy}

Ever since Greek antiquity philosophy has played a decisive role in erecting frontiers, whether between gods and humans, between humans and the world, between truth and falsehood or between good and evil. The influence of Plato, ${ }^{22}$ neo-Platonism and Gnosticism on Christianity and the early fathers is well known. Philosophy accompanied the scientific revolution and helped to establish modernism and, in our time, postmodernism. Although the focus eventually shifted to human beings as knowing subjects, the nature of knowledge and of metaphysical and empirical reality, philosophy determined theology throughout. In this section of the article, we concentrate on Kant, Hegel and Heidegger to follow the movement of metaphysics back to the immanent realm.

Transcendence in philosophy is usually traced to Plato's realm of ideas, in which pure concepts or truths exist an sich, which we can only experience as imperfect reflections in this world. His theory of ideas or forms like truth and the good represents an abstract, immutable, transcendent reality as opposed to the historical, earthly reality of mutability and transience. The underlying motive was to focus on the 'essence' of objects, purging them of subjective, human interpretations. Plato's notion of two worlds (the ideal and the imperfect, earthly reality) is dualistic.

20. Historical Jesus research, too, is just another possible shifting of frontiers based on plausible conjectures. It should not be regarded as undermining or destroying transcendence.

21. Hence the objection of onto-theologians that this portrayal of the transcendent reduces it to a human projection or intra-personal dialogue does not hold water. We cannot prove God's existence or our faith and cannot exceed the limit of human 'seeing as' or 'experiencing as'.

22.Plato's realm of ideas is a noumenal philosophy. Our reality features in it only up to a point.

\section{Transcendence in Kant's thinking}

Despite criticism, Kant's Copernican breakthrough was astounding. It established the knowing subject, confined by its mental structures. It is linked to the proposition of pure reason as a transcendent subject (i.e. a transcendental ego, transcendent in the sense that it is antithetical to objective reality and because it constructs a reality that does not depend on empirical observation). Kant shifted the focus from metaphysical issues about the nature of things (noumenal metaphysics) to the nature (and limits) of human reason. He criticised the metaphysical focus on 'pure objectivity' as dogmatic, for:

any philosophical enquiry in which thinking or reason (act) makes illegitimate claims over being, or in which reason, without proper justification claims being as its possession or as falling under its jurisdiction, or declares itself 'lord' over being, is a form of dogmatism.

(Janz 2004:128) $)^{23}$

Today philosophers have come to realise that the transcendent cannot be known, so they are 'redefining' both transcendence and philosophy:

Philosophy must be assigned its proper limits - assigned, that is, to the event, to the impossibility of escaping the determination of beings as presence. From this point of view, philosophy indeed succeeds in going beyond beings, but only in the direction of the 'what' of beings; thus, philosophy can in no way deal with that which absents itself absolutely.

(Zarader 2003:107)

Transcendence is 'redefined' as follows:

It must be the case that certain 'realities' (whatever their exact identity; it may have to do with being, or God, or the Other) withdraw from all presence, that they be given only in this withdrawal.

(Zarader 2003:107) $)^{24}$

That brings us to the role of the negative, which is crucial in Hegel's thinking (Nancy 1977).

The transcendental approach, we all know, is a search for the a priori conditions for knowledge. To Kant the transcendent is that which excludes (empirical) experience. Empirical study, as Hume indicated, leads to scepticism. As a rule our causal connections are unprovable. The aim was to put an end to metaphysical speculations (e.g. Cartesian ones) and establish philosophy on firm ground by determining what our cognitive structures are capable of and inquiring into their limitations. Often our thoughts exceed our perception. How can we talk about things that are conceivable but not observable? To this end the transcendental ego has recourse to the brain's ability to create a meaningful picture or world by means of categories of thought or understanding. That

23.According to Janz (2004:136) it is this metaphysical focus on the 'nature of things' that led to polarities like aesthesis or noiesis, idealism or realism, empiricism or rationalism, internalism or externalism, anti-realism or realism, etcetera. The metaphysical focus on the nature of things assigns the senses priority and leads metaphysical focus on the nature of things assigns the senses priority and leads 2004:137).

24.Zarader (2004:108) points out that the transcendence of being (in Heidegger's sense) is no more accessible ontologically than God's transcendence is theologically accessible. 'In the onto-theological framework of metaphysics, no authentic transcendence can take place.' 
makes synthetic, a priori judgment possible (without falling prey to Hume's criticism of the causal connections we make). Heidegger puts it as follows:

The fundamental discovery of Kant consists in the realization that these peculiar kinds of knowledge - the preontological understanding of the being of entities and all ontological knowledge - are such as to contain an extension of the knowledge of entities while remaining nonetheless a knowledge which is free from experience and pure. Synthetic judgements a priori are knowledge of this kind. But for Kant this discovery is not the result of his investigation, but its beginning. How are such judgements possible?

(quoted in Lafont 2007:250, n. 4)

The point is that neither our ontological nor our preontological knowledge is written on a blank slate but is bound up with human experiential history that is also implicit in language.

Kant distinguishes between objects perceptible to the senses and non-observable 'objects' - noumena (see the Ding an sich) - which are purely mental constructs, not dependent on sensory perception and not experienced by the senses. The question is whether in this sense God, too, should be regarded as a Ding an sich, a product of pure reason. Kant's postulate of practical reason (God, freedom and immortality) is no less a product of the transcendental ego (pure reason) than that of the Ding an sich. In this regard Janz (2004:169) maintains that to Kant transcendence is 'precisely not real, as theology demands, but purely ideal or purely mental, posited fundamentally as an orienting or regulative device for the understanding'.

Space does not permit me to delve more deeply into Kant's thinking, except to mention that he abstracts pure reason from humanness in its entirety, from the influence of language and empirical experience of the world that indirectly affects our ability to come up with noumenal notions. Yet Kant remains important, because the role of human thought in all reflection - especially reflection on non-observable objects and ideas not grounded in empirical reality - is important for our approach to and understanding of transcendence in that the whole idea of metaphysics is rooted in human consciousness and mental structures. No less important is his criticism of metaphysics, which seeks to prove truths about transcendent objects. Here we merely note that the operation of our cognitive faculties helps us to form ideas. But we need not, like Kant, abolish reason to make room for faith. That would make faith irrational and irrational faith is superstition. Rational faith does not make religion provable, but it does make it more plausible.

\section{Transcendence in Hegel's thinking}

Regardless of criticism of Hegel's idealistic concept of the teleology of Spirit or mind (thought), his insight into the dynamic, versatile interactions of the subject are important. Hegel took on the challenge to 'bridge' the dualism between the transcendent and immanent realms in a unique manner by creatively incorporating negativity (the unknown or foreign or transcendent) into his thinking.
Hegel (1959) wanted to bridge dualisms:

Reason is the highest level of object-thinking. Its false initial assumption of a subject thinking, on one side, and an object alien to it and thought about, on the other side, is an untenable contradiction. In the discovery of this contradiction, reason is driven beyond its standpoint to the concrete dialectical unity of opposites - in this case the subject-object in the comprehensive self-consciousness of life.

(Hegel 1959:212)

In nature spirit is directly present, but it only realises that nature is its own creation when it 'comes home to itself'. Hegel (1959) puts it as follows:

I am this battle, this living opposition in which the opposites are not external to one another, but are inseparably linked. I am not only one of the fighters, but I am both and I am also the battle itself.

(Hegel 1959:30)

That puts an end to alienation:

The Concept - this actual subject-object in process of selfrealization - must restore its integrity out of its self-alienations in which it seems lost. It must mediate its immediacies in order to maintain its balance.

(Hegel 1959:128) $)^{25}$

The outcome of rationalism (the operation of Verstand [intellect] as opposed to Vernunft [reason]) is the creation of dualisms: 'Finite and infinite, simple and complex, one and many, are dialectical opposites: They must be viewed together' (Hegel 1959:86). The distinctions are meaningless. Another attribute of rationalism is that it objectifies things, handling metaphysical entities like God, world, spirit 'as if they were object-images (Vorstellungen) of given finished things' (Hegel 1959:86). 'The Absolute is at once temporal and eternal' (Hegel 1959:112). 'Every self-limitation is also self-transcendence; every "one", by excluding an "other", is defining itself as exclusive of the "other". It is also the "other" of the "other"' (Hegel 1959:112). 'Actuality is the unity of essence and existence, of the inner world of life and the outer world of its appearance' (Hegel 1959:124).

The faith of those who knew Jesus in the flesh only became active after his death. Hegel does not speak of Jesus' resurrection but of his sublation (Aufhebung) - 'an annulling of his real sensible presence and its transfiguration into the modality of spirit' (Hegel 1985:149, n. 231). Consequently sense perception (as an access to reality) is elevated to something else 'and the demand is that this latter should be attested' (Hegel 1985:227). But this happens in a distinctive way, for now it concerns the senses per se, as well as sensory processes and their relation to the mind. Sensory contents are therefore replaced by mind (Hegel 1985:228).

What Hegel manages to do is to dispense with the supernatural or transcendent an sich. God becomes immanent in the mind. It remains at an earthly, natural, sensory level, but sensory contents are now marked by the activity and experience of mind in human consciousness. Žižek (2003) writes:

Insofar as the ultimate Other is God Himself, I should risk the claim that it is the epochal achievement of Christianity to reduce its Otherness to Sameness: God Himself is Man, 'one of us'. If, as 
Hegel emphasizes, what dies on the Cross is the God of beyond itself, the radical Other, then the identification with Christ ('life in Christ') means precisely the suspension of Otherness.

(Žižek 2003:1138)

Put differently: it is not a matter of belief or unbelief in the transcendent (supernatural), but the discovery of transcendence within human beings.

Spirit's mental process is identical with the dialectical dynamics of human thought. Consequently Hegel is able to integrate all dualisms, antitheses and the supernatural with the human mind. Barth (1973) affirms this:

It has been regarded as Hegel's greatest achievement that in his concept of reason, which also embraced historical reality, he finally and justifiably overcame the dualism of transcendental and historical-empirical thought, the dualism of the eternal truth of reason and the accidental truths of history, of destiny and the idea.

(Barth 1973:392)

This is accomplished by reason, 'not by referring to some intuitive and emotional Beyond, which could not be apprehended, but only experienced' (Barth 1973:392).

\section{Transcendence in Heidegger's thinking}

Heidegger is important for our reflection, because he considered it impossible to think about transcendence unless we grasp the nature of being (especially in the mode of Dasein). Consequently he assimilated the transcendent into human existence. He rejects Kant's idea that the a priori conditions of experience are products of the faculties of pure reason. Instead he traces their origin to the temporality of Dasein (Crowell \& Malpas 2007:4). Consequently he links transcendence with being and the enlightening revelation of being that emerge in human life. ${ }^{25}$

Whereas Kant tried to reconcile transcendental idealism with empirical realism, Heidegger seeks to reconcile ontological realism with ontological idealism (Lafont 2007:106). Hence Heidegger avoids transcendental idealism, which is purely metaphysical. The world is not made up of self-identifying entities. It is we who carve up reality by the way we understand existence. 'As Heidegger would put it, that there are entities has nothing to do with us, but what they are depends on our prior projection of their being' (Lafont 2007:106). She continues: 'Being must be projected in advance in order for entities to be accessible as such entities' (Lafont 2007:108). Heidegger explains it as follows:

We wish to consider the essence of truth. 'Truth': what is that? The answer to the question 'what is that?' brings us to the 'essence' of a thing. 'Table': what is that? 'Mountain', 'ocean', 'plant'; in each case the question 'what is that?' asks about the 'essence' of these things. We ask - and already know them! Indeed, must we not already know them, in order afterward to ask, and even to give an answer, about what they are? ... Clearly we must necessarily already know the essence. For how otherwise could we know

25.According to Philipse (quoted in Cromwell and Malpas [2007:8]), Heidegger's emphasis on the life world is the reason why his 'realism' excludes scientific realism. That is because the reality (realism) in which he locates being is not the reality of scientific research. what we should provide when we are requested to name truths? ... We must already know what and how the thing is about which we speak.

(Lafont 2007:108)

So understanding is possible only because we are already projecting understanding.

We are now in a position to shed more light on the encounter with God as the transcendent. We have seen that this experience of encounter is such that it affords insight into our self-understanding, reinterpreting it and changing it. But how can encounter with the unknown, with mystery greater than we can conceive of, have that effect? The answer is that we do not approach anything with a blank slate, not even the unknown transcendent. We 'know' what the unknowable God is, because we project meaning derived from our tradition, experience, intuition, intentionality and the like in other words, humanly immanent projected meaning. Does that take us back to Feuerbach's projection theory? But the projected meaning is experienced as reality; its 'substance' changes in the process of encountering the idea (projection) as a reality. In fact, our expectations (projected meanings) are indispensable for encountering the transcendent: God the loving creator, caring mother, compassionate father will hear me and help me in my distress. Accordingly what happens to us is interpreted in light of our expectations: he answered me, gave me insight and changed my lot. The condition that 'you only have to believe' is a filter introduced as a condition for salvation. 'Belief' is also linked to the specific denomination's interpretation of it and presupposes a substantial God concept: 'He exists, for I believe.' Conversely, it comes down to the question of whether humans are affected existentially. It implies that experience 'from below' ${ }^{26}$ is a condition for knowledge about transcendence.

\section{Transcendence in science}

Science as we know it today was a latecomer on the stage of human thought, even though the early cosmologists and Aristotle left a lasting imprint. But this lastborn child of the 15th century scientific revolution soon started dominating the family conversation. Ironically, science - which tolerates no division between nature and the supernatural and has no taste for cross-border dialogue - contributed to the proverbial Copernican revolution in our world view and helped to shift the frontiers of the transcendent. Not only did it expose the secrets of the cosmos; it actually probed the mystery of life itself. The sciences have enabled us to explain transcendent reality in purely immanent terms. By describing and explaining transcendence, science sacrifices on the altar of its research all the powers, gods and superstitions

26.Thus Gill (1989:14), referring to Marcel, Maritain and Kierkegaard, says they find human existence absurd in the light of traditional philosophy, 'while affirming the meaningfulness of the transcendent in relation to existential realities, values, and decisions... In this purview, the transcendent remains viable, but only as the "horizon" or "ground" of existence and meaning. It is neither "beyond" this world à la Plato, nor in this world by way of divine intervention (miracles, etc.). In Kant's terminology, transcendence has taken on a "regulative" function rather than a "substantive" one.' Gill himself works out a mediated or dimensional view of a "substantive" one." Gill himself works out a mediated or dimensional view of transcendence: "I would propose a dimensional model. The basic difference lies in understanding reality as composed of a number of simultaneous interpenetrating imensions rather than as separate levels or domains' (Gill 1989:20). 'Mediationa transcendence overcomes the inherent modern approach to ontology, pistemology, ethics and linguistic meaning by focusing on the participatory and interactive character of reality, knowledge, behavior, and speech' (Gill 1989:154). 
that have governed humankind over the ages. Our world is disenchanted. The neurosciences have even named our most intimate experiences of God: the moment of Absolute Unitary Being (AUB), when human brain processes induce an experience of ineffable union with the deity.

In the science-religion debate scientists actually come to the rescue of the gods by looking for openings that permit them to act in the world as we see it today. They erect a frontier post, an in-between zone for divine action in the form of the decisive role of chance in evolution. Initially the debate was dominated by the question of God's action in the world and it persists. But one cannot but wonder whether it is not just a loophole for making God more plausible to the modern scientific mind.

\section{New cosmology debate}

The new cosmology debate has explored numerous possibilities to accommodate God's actions on earth without jeopardising the integrity of natural laws. The premise is that God voluntarily submits to laws that he himself decreed. The trend known as intelligent design was largely rejected and attempts to find an acceptable 'work place', a 'causal joint' where God can 'intervene' without violating natural laws have not been conspicuously successful either.

The openings or frontier posts found in science-theology debates where God can act (in a non-interventionist manner) are at the micro level of quantum uncertainty, ${ }^{27}$ complexity systems, the role of chance in evolution, autopoietic (self-creating) cell systems in biology, ${ }^{28}$ and the notion of emergence..$^{29}$ Of course, the critical question here

27. Hanna Arendt accuses both religion and science of contributing to people's 'worldless-ness' and alienation. Science alienates us from the earth: 'At any event, while world alienation determined the course and development of modern society, earth alienation became and has remained the hallmark of modern science. Under the sign of earth alienation, every science, not only physical and natura science, so radically changed its innermost content that one may doubt whethe prior to the modern age anything like science existed at all' (Arendt 1958:264). To Arendt this alienation is symbolised by the language of physical science, namely algebra. Mathematics permits humans to 'rule' over nature without (alienate from) any natural aids. It is no longer interested in observation, its sole concern is the structure of human thought (Arendt 1958:266): 'Man realized his newly won freedom from the shackles of earth-bound experience; instead of observing natura phenomena as they were given to him, he placed nature under the condition of his own mind, that is, under conditions won from a universal, astrophysica viewpoint a cosmic standpoint outside nature itself' (Arendt 1958.265). In this sense mathematics is cosmically universal yet world-less. As 'universal' science, sense mathematics is cosmically universal yet world-less. As universal science, mathematics imports cosmic processes into nature, incurring a manifest risk Which, along with human mastery of nature, makes it possible to destroy nature. With reference to Schrödinger's uncertainty principle Arendt (1958:288) writes: "With the disappearance of the sensually given world, that transcendent world disappears as well, and with it the possibility of transcending the material world in concept and thought. It is therefore not surprising that the new universe is no only "practically inaccessible but not even thinkable", for however we think it, is wrong... That would imply that reality (nature and being) is inaccessible to ou senses, but also to pure reason. Maybe all that is changing and the 21st century the earth. Whereas the 20th century was the age of physics, the 21st century will probably be the age of biology and bring us closer to our roots in nature.

28.Davies (2008:48) relativises the 'openness' at a cellular level: 'The cell has room for this supra-molecular coordination because it is an open system, so its dynamical behaviour is not determined from within the system. But openness to the environment merely explains why there may be room for top-down causation it tells us nothing about how that causation works.'

29.Stuart Kaufman maintains, as indicated by the title of his book Reinventing the sacred, that the time is ripe and that we are now in a position to reinvent the sacred: 'A Creator God is not needed for the origin of life' (Kaufman 2008:4). As a scientist, however, Kaufmann is an anti-reductionist, believing that the emergence model, (Kafman 2008:7-9). He writes: 'It liences Kaufman 2008:7-9). He writes: 'It lies beyond reductionism. Life has emerged in the univere without Hequing specialintervention from a Creator God. Should that the biosphere? No. Because we hold life to be sacred, we are stepping towards the the biosphere? No. Because we hold life to be sacred, we are stepping towar
reinvention of the sacred as the creativity in nature' (Kaufman 2008:71). is this: if a 'plausible' space is found where God can act non-interventionistically, why doesn't he use it? Why does the reality of suffering and evil still prevail? It also raises the question of human freedom and determinism..$^{30}$ If God exercises his will at quantum level, where do our will and freedom feature? This approach moreover rules out personal encounter with God. We cannot genuinely communicate with a god who operates at quantum level. This discourse must be regarded as an attempt to smuggle in modern-day proofs of God's existence, which inevitably entails a new noumenal metaphysics (an omnipotent, omnipresent God controlling everything). Hence the God concept underlying the anthropic principle and the models that leave scope for divine action remain trapped in the theistic metaphysics that they have to defend (see Du Toit 2007).

Another development in this debate does not necessarily look for openings for non-interventionist divine action but uses human biology as a basis for a purely immanent view of religion. It has the advantage that God acts via human brain processes, which is a more acceptable explanation than, for example, that of quantum uncertainty. Here the cognitive and brain sciences come to mind. D'Aquily and Newberg (1999) did ground-breaking work in this field (also see Du Toit [2002]). I merely mention this development because it defines the transcendent wiring of our biology, especially as it manifests itself in religions. These authors' definition of religion puts the accent on a culture's needs and how they are fulfilled by way of 'salvation' by super-sensible powers and forces. Usually it concerns total, absolute, sometimes transcendent fulfilment of human needs (D'Aquily \& Newberg 1999:149). They propose a kind of 'neurotheology' (D'Aquily \& Newberg 1999:163ff), based on certain brain functions that 'explain' various aspects of religion: 'We feel certain, however, that any specific theological idea may eventually be reducible to neuropsychological functions' (D'Aquily \& Newberg 1999:175). Of course, the approach is reductive and to my mind it at most sheds some light on theological ideas and experiences of God. They identify the following functions: holistic operator (D'Aquily \& Newberg 1999:166-168); reductionist operator (D'Aquily \& Newberg 1999:168-169); quantitative operator (D'Aquily \& Newberg 1999:169-170); binary operator (D'Aquily \& Newberg 1999:170); causal operator (D'Aquily \& Newberg 1999:170-172); abstractive operator (D'Aquily \& Newberg 1999:173-174); and the attention association and orientation association areas (D'Aquily \& Newberg 1999:174-175). I do not propose to dwell on these here. It is sufficient to emphasise that we cannot reflect on transcendence without taking our own biology into account. But identifying the neurological mechanisms that explain certain religious experiences, mental categories and dispositions does not help us to evaluate their contents. That is where theology and philosophy can contribute most. At all events, our biology, more particularly the actual operation of human thought and the thought-brain relation, remain enigmatic.

30.Paul Davies (2008:48) also points out that standard quantum mechanics 'is really a deterministic theory in its dynamics, even though it predictions are statistical'. 


\section{Conclusion}

This somewhat eclectic overview of the history of theology, philosophy and science seeks to fathom how transcendentlywired human beings conceive of and are affected by transcendence. The basic assumption, using the metaphor of frontiers and frontier posts, is that the frontiers of transcendence shift according to the questions and insights of the age, but that the actual operation of transcendence remains unchanged. Historically one can focus on transcendence in various modes: a noumenal metaphysical view (Plato, neo-Platonism, Augustine, Anselm, etc.); the angle of the human subject (God as a Kantian postulate, Schleiermacher, postmodern subject philosophy); the mode of interaction with negativity, a process in which both our self-understanding and our understanding of God or the Absolute changes and develops (Hegel, Jüngel); the mode which assimilates God into our historically contingent life world (Heidegger); the scientific mode that proposes empirical openings for divine action; and the brain sciences that offer physical explanations of transcendent experiences. The various modes relate to the filters that each of them uses to 'express' transcendence.

The approach proposed in this article is that of immanent transcendence: the transcendent is experienced in thisworldly immanence as startlingly new; tragic; unknown; a reinterpretation of the known; and a gateway to the future. It is the epiphany of the Totally Other in the ordinary, known world, the Ding an sich as Ding für mich. In whatever form the transcendent is encountered, it happens via the light it sheds on human beings. That light may be experienced as existential illumination (Lichtung), the 'aha!' experience of a new scientific discovery, or a religious born-again experience; or negatively in the form of suffering and tragedy. Without this light we are unable to understand ourselves and our world. It is this binary structure, the tension of an ever-luring future, that distinguishes our existence. The light does not come through a revelation of God's being, the Absolute or Ding an sich. When we cross the frontier to transcendence, we discover the 'explained' replica of ourselves on the far side. But the self we discover is different: it has been changed by the act of 'crossing'. That is the Hegelian movement of Spirit (mind), in which encounter with the Object, the Unknown, the Negative, the Other not only changes the object (it changes 'physically', because our perception or understanding of it changes), but we ourselves change. No frontier ever shifts without changing us (Hegel).

In theology and philosophy the frontier of transcendence shifted from the metaphysical belief that the very essence of the Other or Truth or Transcendence can be known, to an openness to transcendence at the historical, immanent level. The result is a horizontal transcendence. Science has contributed a lot to our understanding of our physical wiring for transcendence. In the sciences the metaphysics of exclusively empirical 'knowledge' evolved to a point where empirical exactitude succumbed to uncertainty, which allows for chance, the subject, complexity and emergence. Here transcendence is marked by the notion of emergence, which again focuses the search for transcendence on a reality that describes us, not one that we describe.

Their research is not confined to the problem of God's actions in the world. Human evolutionary history and mental experience of transcendence are studied. The message is that in all religious experience earthly immanent factors are crucial. Wherever we locate the frontier of transcendence, it remains thoroughly human, whether we wrap it in metaphors, metaphysics, apophatic theologies, mystical experience or quantum uncertainty. The encounter with transcendence derives its power from the meaning it imparts to the human condition. The secret of faith is that we do not stare ourselves blind at the vehicle (metaphysics, mystical experience, enlightenment, etc.). 'Crossing' that frontier in itself is enlightening, which is not the same as detached theorising about an objectified transcendence.

\section{Acknowledgement}

This article is a tribute to Andries van Aarde and his commitment to shifting hermeneutic boundaries in Jesus research.

\section{References}

Armstrong, K., 2009, The case for God. What religion really means, Bodley Head, London.

Barth, K., 1973, Protestant theology in the nineteenth century, Judson Press, London. Berger, H., 1993, Wat is metafysica? Een studie over transcendentie, Van Gorcum, Assen

Berkhof, H., 1973, Christeljik geloof, Uitgeverij G.F., Callenbach, Nijkerk.

Brons, R., 2002, 'Postmodern thinking of transcendence', in H.J. Silverman (ed.), Lyotard. Philosophy, politics, and the sublime, Routledge, pp. 179-191, New York \& London.

Chidester, D., 2002, Patterns of transcendence. Religion, death and dying, Wadsworth, Belmont, CA.

Clayton, P. \& Davies, P. (eds.), 2008, The re-emergence of emergence. The emergentist hypothesis from science to religion, Oxford University Press, Oxford \& New York.

Crowell, S. \& Malpas, J. (eds.), 2007, Transcendental Heidegger, Stanford University Press, Stanford

Crowell, S. \& Malpas, J., 2007, 'Introduction: Transcendental Heidegger', in S. Crowell \& J. Malpas (eds.), Transcendental Heidegger, pp. 1-9, Stanford University Press, Stanford.

D’Aquili, E. \& Newberg, A.B., 1999, The mystic mind. Probing the biology of religious experience, Fortress, Minneapolis.

Davies, P., 2008, 'The physics of downward causation', in P. Clayton \& P. Davies (eds.), The re-emergence of emergence. The emergentist hypothesis from science to religion, pp. 35-51, Oxford University Press, Oxford \& New York.

Desmond, W., 1995, Being and the between, State University of New York, Albany.

Du Toit, C.W., 2002, Brain, mind and soul. Unifying the human self, RITR, Unisa, Pretoria.

Du Toit, C.W., 2007, Viewed from the shoulders of God: Themes in science and theology, RITR, Unisa, Pretoria

Du Toit, C.W., 2009, 'An immanent approach to death: Theological implications of a secular view', HTS Teologiese Studies/Theological Studies 65, 3.

Du Toit, C.W., 2010, 'Perspectives on an ethics of power sharing in Africa', in C.W. du Toit (ed.), Power sharing and African democracy. Interdisciplinary perspectives, pp. 45-69, RITR, Unisa, Pretoria.

Faulconer, J.E. (ed.), 2003, Transcendence in philosophy and religion, Indiana University Press, Bloomington \& Indianapolis.

Gill, J.H., 1989, Mediated transcendence. A postmodern reflection, Mercer University Press, Macon, GA.

Hegel, G.W.F., 1959, Encyclopedia of philosophy, transl. G.E. Mueller, Philosophical Library, New York.

Hegel, G.W.F., 1985, Vol. III: The consummate religion, Lectures on the philosophy of religion, University of California Press, Berkeley, Los Angeles, London.

Hick, J., 1997, 'Transcendence and truth', in D.Z. Philips \&T. Tessin (eds.), Religion without transcendence?, pp. 41-59, Macmillan, London.

Hick, J., 2006, Religious experience, neuroscience and the transcendent, Palgrave, London. 
Holmstrand, I., 1980, Karl Heim on philosophy, science and the transcendence of God, Almqvist \& Wiksell, Stockholm

Janz, P.D., 2004, God, the mind's desire. Reference, reason and Christian thinking Cambridge University Press, Cambridge.

Johnson, W.A., 1974, The search for transcendence. A theological analysis of nontheological attempts to define transcendence, Harper \& Row, New York, Evanston, San Francisco, London.

Kaufmann, S.A., 2008, Reinventing the sacred. A new view of science, reason, and religion, Basic, New York.

Lafont, C., 2007, 'Heidegger and the synthetic a-priori', in S. Crowell \& J. Malpas (eds.), Transcendental Heidegger, pp. 104-118, Stanford University Press, Stanford.
Nancy, J.-L., 1977, Hegel. The restlessness of the negative, University of Minnesota Press, Minneapolis, London.

Philips, D.Z. \&Tessin, T. (eds.), 1997, Religion without transcendence?, Macmillan, London.

Ryle, G., 1949, The concept of mind, Penguin, Harmondsworth.

Weber, O., 1972, Grundlagen der Dogmatik II, Neukirchener Verlag, Germany. Wood, D., 2007, Time after time, Indiana University Press, Bloomington \& Indianapolis.

Zarader, M., 2003, 'Phenomenality and transcendence', in J.E. Faulconer (ed.), Transcendence in philosophy and religion, pp. 106-119, Indiana University Press, Bloomington \& Indianapolis.

Žižek, S., 2003, The puppet and the dwarf, MIT, Cambridge (MA) \& London. 